\title{
Implementasi Teori Perkembangan Kognitif Jean Piaget dalam Pembelajaran Matematika di Sekolah Dasar
}

\author{
Nuryati $^{1_{\circledast}}$ \& Darsinah $^{2}$ \\ Prodi Magister Pendidikan Dasar, Universitas Muhammadiyah Surakarta, Indonesia \\ $\bowtie$ E-mail: aka80794@gmail.com
}

\begin{abstract}
Abstrak
Tujuan penelitian ini adalah untuk mengkaji lebih jauh tentang teori perkembangan kognitif oleh Jean Piaget terhadap pembelajaran matematika sesuai tingkat berfikir anak pada tahap usia Sekolah Dasar. Sumber data yang digunakan dalam penelitian ini yaitu buku, jurnal, artikel, dan karya ilmiah lainnya. Teknik pengumpulan datanya adalah Studi Pustaka. Analisis data menggunakan content analysis. Hasil penelitian ini menunjukkan bahwa perkembangan kognitif anak pada tahap usia operasional konkret (7-12 tahun) dalam pembelajaran matematika ini berbeda-beda hampir pada setiap fase usianya. Pembelajaran matematika di Sekolah Dasar disesuaikan dengan tahapan usia. Hal ini sesuai dengan implementasi teori perkembangan Jean Piaget. Merujuk pada bagaimana orang tumbuh, menyesuaikan diri, dan berubah sepanjang perjalanan hidupnya melalui perkembangan fisik, perkembangan kepribadian, perkembangan sosioemosi, perkembangan kognisi (pemikiran), dan perkembangan bahasa. Selain tingkat pemahaman model dan metode serta penanganan yang digunakan juga bervariatif. Hasil penelitian dapat menjadi landasan guru mengajar sehingga pembelajaran menjadi lebih efektif, efisien, dan tepat sasaran. Terlebih untuk mewujudkan tercapainya tujuan pendidikan nasional.
\end{abstract}

Kata Kunci: Kognitif; Jean Piaget; Pembelajaran Matematika; Sekolah Dasar.

\begin{abstract}
The purpose of this study was to further examine Jean Piaget's theory of cognitive development about learning mathematics according to the level of thinking of children at the elementary school age stage. Sources of data used in this research are books, journals, articles, and other scientific works. The data collection technique is Literature Study. Data analysis using content analysis. The results of this study indicate that the cognitive development of children at the stage of concrete operational age (7-12 years) in learning mathematics is almost different at each age stage. Learning mathematics in elementary schools is adjusted to the stages of age. This is in accordance with the application of Jean Piaget's theory of development. Refers to how humans grow, adapt, and change throughout the course of their lives through physical development, personality development, socio-emotional development, cognitive development (thinking), and language development. The results of these studies can be the basis for teachers to teach so that learning becomes more effective, efficient, and on target. Especially to realize the achievement of national education goals.
\end{abstract}

Keyword; Cognitive; Jean Piaget; Mathematic Learning; Elementary School. 


\section{PENDAHULUAN}

Perkembangan merupakan proses perubahan psikis dan juga psikis yang dialami oleh setiap manusia yang nantinya mengalami peningkatan atau progress kematangan dalam hidupnya (Khaulani et al., 2020). Kognitif bisa dikatakan suatu bagian psikologis yang diantaranya berupa perilaku mental urusannya dalam kemampuan mempertimbangkan, menyelesaikan masalah, memahami, mengolah informasi, kemantapan serta kesengajaan, sehingga kognitif bisa diartikan suatu psikologis individu yang berkaitan dengan pengetahuan yang dimiliki.

Fungsi-fungsi psikologis yang ada pada tiap individu mempunyai kaitan dengan perkembangan kognitif. Berkembangnya suatu pikiran seseorang disebut sebagai perkembangan kognitif. Apa saja yang menjadi bahan pemikiran anak merupakan isi dari otaknya yang memiliki tanggung jawab dalam berbahasa, membentuk mental, memahami, memecahkan masalah, sudut pandang,menilai, memahami sebab akibat, dan juga ingatan. Perkembangan kognitif dialami olehsetiap individu dari mereka lahir, bayi, anak-anak, remaja hingga dewasa dan akan terus selalu berkembang.

Belajar kognitif berjalan berdasarkan struktur mental seseorang yang mengorganisasikan hasil dari yang diamatinya. Mental seseorang itu meningkat berdasarkan tingkat perkembangan kognisiyang dialami individu itu. Jika perkembangan kognisi individu meningkat secara unggul, maka ia akan mampu dan terampil dalam mengolahsegalapengetahuan yang diterima dari sekitarnya juga akan semakin unggul pula.Perkembangan kognitif seringkali bergantung pada tingkat keaktifan anak dalam keaktifannya berhubungan dengan kalangan sekitarnya (Mifroh, 2020).
Teori Perkembangan kognitif ini Jean Piaget berpendapat bahwa terdapat tiga aspek dalam perkembangan kognitif setiap individu, meliputi:isi,struktur, dan fungsi kognitif. Isi kognitif kaitannya dengan tingkah laku seseorang yang dapat dilihat ketika ia menanggapi berbagai masalah. Struktur kognitif merupakan organisasi mental yang terbentuk ketika seseorang berhubungan dengan lingkungan dimana ia berada dan fungsi kognitif merupakan cara yang seseorang untuk meningkatkan intelektualnya.

Menurut Piaget (Waseso, 2018) tingkah laku seseorang senantiasa didasarkan pada kognisi, yakni suatu tindakan untuk mengenal atau memikirkan kondisi dimana suatu perilaku itu terjadi. Secara tidak langsung pribadi anak terbentuk melalui proses belajar yang melibatkan proses berfikir kompleks dan merupakan peristiwa mental yang nantinya dapat mendorong terjadinya sikap dan perilaku.

Pandangan dunia anak tahap operasional konkret (7-12 tahun) berbeda dengan pandangan orang tua atau yang lebih dewasa, jadi pendidik harus mampu mendorong anak untuk membentuk konsep yang tepat khususnya dalam pembelajaran matematika. Pelaksanaan praktik pembelajaran matematika di Indonesia sangat dipengaruhi oleh teori belajar kognitif. Berbagai upaya yang telah dirintis untuk memperbaiki praktek pembelajaran matematika dengan berpegang pada aliran kognitif. Teori belajar kognitif diyakini sebagai upaya pembaharuan atau inovasi belajar yang diharapkan mampu memperbaiki kualitas pendidikan matematika di Indonesia.

\section{METODE PENELITIAN}

Metode penelitiannya deskriptif, 
penelitian deskriptif berfokus pada penjelasan sistematis tentang fakta yang diperoleh saat penelitian dilakukan. Teknik pengumpulan datanya menggunkan studi pustaka. Studi pustaka berisi teori yang relevan dengan masalah-masalah penelitian. Adapun masalah pada penelitian ini adalah untuk mengetahui tentang Teori Perkembangan anak usia Sekolah Dasar dalam pembelajaran dengan menggunkan implementasi teori perkembangan Jean Piaget. Penelitian mengacu pada jurnal yang memiliki relevans kata kunci pada judul. Kata kunci yang digunakan adalah; Teori Kognitif jean piaget, fase dan tahap perkembangan anak pada usia Sekolah Dasar, dan Mata pelajaran Matematika.

Teknik analisis data setelah keseluruhan data terkumpul, langkah selanjutnya penulis menganalisa data tersebut sehingga ditarik suatu kesimpulan. Untuk memperoleh hasil yang benar dan tepat dalam menganalisa data penulis menggunakan teknik analisis isi. Analisis isi adalah penelitian yang bersifat pembahasan mendalam terhadap suatu informasi tertulis atau tercetak di media massa. Analisis dapat digunakan untuk menganalisa semua bentuk komunikasi, baik surat kabar, berita radio, iklan televisi maupun semua bahan dokumentasi yang lainnya.

\section{HASIL DAN PEMBAHASAN \\ Implementasi Teori Perkembangan Kognitif Jean Piaget}

Teori Perkembangan Kognitif Jean Piaget merujuk pada bagaimana orang tumbuh, menyesuaikan diri, dan berubah sepanjang perjalanan hidupnya melalui perkembangan fisik, perkembangan kepribadian, perkembangan sosioemosi, perkembangan kognisi (pemikiran), dan perkembangan bahasa (Khiyarusoleh, 2016).
Istilah cognitive berasal dari kata cognition kesamannya knowing, berarti mengetahui. Dalam arti yang luas cognitive (kognisi) ialah perolehan, penataan, dan Analisis Teori Perkembangan Kognitif Piaget. Teori kognitif menjadi popular sebagai salah satu domain atau ranah psikologis manusia. Ranah psikologis yang meliputi perilaku mental yang berhubungan dengan pemahaman, pertimbangan, pengolahan informasi, pemecahan masalah, kesengajaan, dan keyakinan. Ranah kejiwaaan berpusat pada otak dan juga berhubungan dengan konasi (kehendak) dan afeksi (perasaan) yang bertalian dengan ranah rasa.

Teori perkembangan kognitif Piaget menjelasakan bagaimana cara anak dapat beradaptasi dan menginterpretasikan dengan objek serta kejadian di sekitarnya. Bagaimana cara anak mempelajari ciri dan fungsi dari objek seperti mainan, perabot, dan makanan serta objek-objek sosial seperti diri, orangtua, dan teman. Serta bagaimana cara mengelompokkan objek-objek untuk mengetahui persamaan-persamaan dan perbedaan-perbedaannya, untuk memahami penyebab terjadinya perubahan dalam objekobjek dan perisiwa-peristiwa dan untuk membentuk perkiraan tentang objek-objek dan peristiwa tersebut(Basri, 2018).

Konsep perkembangan Piaget sebagai berikut (Juwantara, 2019); (1) Skema ketika anak berusaha untuk membangun pemahaman mengenai dunia, otak berkembang menciptakan skema. Ini adalah tindakan atau representasi mental yang merorganisasikan pengetahuan. Dalam teori Piaget, skema perilaku (aktivitas fisik) ciri bayi, dan skema mental (kegiatan kognitif), berkembang di masa kanak-kanak. (2) Asimilasi adalah konsep Piaget tentang tergabungnya informasi baru kedalam pengetahuan yang ada (skema). 
Akomodasi merupakan konsep Piaget tentang pengelompokan perilaku terisolasi ke tatanan sistem kognitif yang lebih tinggi dengan fungsi yang lebih baik. (4) Organisasi dalam teori Piaget adalah pengelompokan perilaku dan pikiran yang terisolasi ke dalam sistemyang lebih tinggi. Menunjuk pada tendensi semua spesies untuk mengadakan sistematisasi dan mengorganisasi proses-proses mereka dalam suatu sistem yang koheren, baik secara fisis maupun psikologis. (5) Ekuilibrasi merupakan mekanisme untuk menjelaskan bagaimana anak-anak berpindah dari satu tahap pemikiran ke tahap berikutnya. Pergeseran ini terjadi karena anak mengalami konflik kognitif (disekuilibrium), dalam mencoba untuk memahami dunia.

Piaget menytakan belajar akan berhasil apabila disesuaikan dengan tahap perkembangan kognitif peserta didik. Pemahaman tersebut sangat penting untuk memberikan kesempatan bagi peserta didik melakukan eksperimen bersama kelompok teman-temannya dan dibantu oleh pertanyaan tilikan dari pendidik. Pendidik memainkan peran penting dalam proses tersebut dengan memberikan rangsangan kepada peserta didik dengan tujuan dalam pembelajaran terjadi interaksi dengan lingkungan secara aktif, dan mencari serta menemukan berbagai hal dari lingkungan.

\section{Perkembangan Kognitif Anak Sekolah} Dasar

Perkembangan kognitif merupakan pertumbuhan berfikir logis dari masa bayi hingga dewasa, menurut Piaget perkembangan yang berlangsung melalui empat tahap, yaitu: tahap perkembangan tahap sensori-motor pada usia $0-1,5$ tahun, tahap pra-operasional pada usia1,5 - 6 tahun , tahap operasional konkrit pada usia 6-12 tahun dan tahap operasional formal 12 tahun ke atas (Basri, 2018).

Setiap tahap perkembangan masuk ketika otak kita sudah cukup matang dan memungkinkan logika jenis baru melalui setiap tingkat, tetapi dengan kecepatan yang berbeda, jadi mungkin saja seorang anak yang berusia 6 tahun berada pada tingkat operasional konkrit, sedangkan ada seorang anak yang berusia 8 tahun masih pada tingkat pra-operasional dalam cara berfikir. Namun pada urutan perkembangan intelektual untuk semua anak sama, dan struktur untuk tingkat sebelumnya terintegrasi dan termasuk sebagai bagian dari tingkatan berikutnya.

Pada tahap Operasional Konkret anak sudah cukup matang untuk menggunakan pemikiran logika atau operasi, tetapi hanya untuk objek fisik yang ada saat ini. Pada tahap ini, anak cenderung kehilangan terhadap animisme dan articialisme. Egosentrisnya mulai berkurang dan kemampuan dalam tugas konservasi menjadi lebih baik. Tanpa objek fisik dan nyata di hadapan mereka, anak-anak pada tahap operasional kongkrit masih mengalami kesulitan besar dalam menyelesaikan tugastugas logikanya. Anak juga mengembangkan kemampuannya untuk mempertahankan, kemampuan mengelompokkan secara memadai, melakukan pengurutan dan menangani konsep angka. Selama tahap ini proses pemikiran diarahkan pada kejadian nyata yang diamati oleh anak. Anak dapat melakukan operasi problem yang agak kompleks selama problem itu konkret dan tidak abstrak (Juwantara, 2019).

\section{Prinsip-Prinsip Pembelajaran kognitif}

Prinsip pembelajaran kognitif meliputi tiga prinsip utama pembelajaran yang dikemukakan Piaget sebagai berikut (Waseso, 2018): (1)Belajar aktif proses pembelajaran adalah proses aktif, sebab 
pengetahuan terbentuk dari dalam subyek belajar. Untuk membantu perkembangan kognitif anak, kepadanya perlu diciptakan suatu kondisi belajar yang memungkinkan anak belajar sendiri, misalnya melakukan percobaan dengan memanipulasi simbolsimbol, mengajukan pertanyaan dan mencari jawaban sendiri, atau membandingkan penemuan sendiri dengan penemuan temannya. (2) Belajar Lewat Interaksi Sosial Dalam belajar; dengan cara menciptakan suasana yang memungkinkan terjadinya interaksi antara subyek belajar. Belajar bersama teman sebaya dan orang dewasa akan membantu perkembangan kognitif mereka. Dengan kebersamaan, kognitif anak akan berkembang dan menghilangkan sifat egosentris. (3) Belajar Lewat Pengalaman Sendiri Dengan memanfaatkan pengalaman nyata, perkembangan kognitif seseorang akan lebih baik daripada hanya menggunakan bahasa untuk berkomunikasi. Namun, jika tidak diikuti penerapan dan pengalaman maka perkembangan kognitif seseorang akan cenderung mengarah ke verbalisme.

\section{Implementasi Teori Jean Piaget Dalam Pembelajaran Matematika}

Matematika sekolah merupakan matematika yang telah dipilah-pilah dan disesuaikan dengan tahap perkembangan intelektual siswa dan matematika salah satu ilmu yang digunakan sebagai sarana dalam mengembangkan kemampuan berpikir bagi para siswa. Perbedaan antara matematika sebagai ilmu dengan matematika sekolah memiliki sedikit perbedaan. Perbedaan itu dalam bentuk penyajiannya, pola pikir, keterbatasan semesta, dan tingkat keabstrakannya (Muslihatun et al., 2019).

Matematika (Safitri et al., 2021) merupakan ilmu pengetahuan yang objek kajiannya bersifat abstrak sehingga memerlukan penalaran deduktif untuk memahaminya. Pembelajaran matematika selalu dikaitkan dengan kesiapan kognitif dan proses belajranya dipandang sebagai hasil pencapaian dan perkembangan dari struktur kognitif. Kesiapan belajar anak ditinjau dari kesiapan struktur kognitifnya, yaitu kapasitas kemampuan berpikir secara terorganisir dan terkoordinir. Struktur kognitif diperlukan sebagai cara untuk mengembangkan kemampuan penalaran yang dapat distimulasi melalui pengkajian matematis suatu objek.

Kegiatan pembelajaran matematika pada tahap operasional konkret harus memperhatikan karakter anak. Pada mata pelajaran matematika salah satu tujuan pembelajarannya adalah tujuan praktis. Tujuan praktis (practical goal) ini berkaitan dengan pengembangan kemampuan siswa untuk menggunakan matematika untuk menyelesaikan masalah yang terkait dengan kehidupan sehari-hari. Dari salah satu tujuan ini, maka dalam mendidik anak disesuaikan dengan tahap perkembangan berpikirnya. Adapun dalam proses pembelajaran harus memperhatikan tingkatan kognitif anak, model atau strategi pembelajaran dan materi pembelajaran sesuai dengan tingkatannya.

Adapun deskripsi perkembangan anak dalam pembelajaran matematika sebagai berikut:

Pertama Kemampuan kognitif anak usia 7 tahun (kelas satu SD/MI); Kemampuan kognitif anak pada usia ini masih pada tahap pengetahuan dan pemahaman yang masih terbatas, meskipun anak sudah masuk ada fase operasional konkret. Pada Konteks pendidikan, mengacu pada teori Taksonomi Bloom bahwa pada fase ini anak memasuki jenjang yang paling rendah yaitu $\mathrm{C} 1$ (mengingat) dan fase awal jenjang C2 (memahami). Kata operasional 
(verb) pada fase ini seperti menyusun daftar, mengingat, menyebutkan, mengenali, menuliskan kembali, mengulang, memberi nama, mengelompokkan suatu benda dan mampu membedakan sesuatu yang sifanta simple (Anugraheni, 2018).

Pembelajaran matematika pada tahap ini sebaiknya menggunakan alat bantu seperti mesin hitung manual, jari tangan, gambar yang detil dan menggunakan bantuan benda seperti buah, batu, kertas dan sebagainya. Pada tahap ini, anak-anak juga sudah bisa dikenal kanjenis-jenis warna dan symbol-simbol sederhana, seperti lambanglambang, bentuk bangun datar dan bendabenda yang terdapat di lingkungan sekitar.

Metode pembelajaran yang digunakan adlah pembelajaran kontekstual dengan mengkaitkan materi dengan kondisi nyata dan berhubungan dengan kehidupan seharihari. Anak bisa diajak ke luar kelas untuk melakukan pembelajaran agar tidak merasakan penat, dikarenakan anak berusia 6 hingga 7 tahun lebih cepat merasa lelah dalam berfikir. Pada proseskegiatan belajar mengajar, hendaknya guru mendidiknya dan mengajarnya secara intens, karena pada tahap ini, kondisi anak ada pada masa bermain yang membutuhkan kesenangan. Anak-anak belum bisa belajar dengan nuansa yang formal, sehingga guru mesti kreatif mendesain pembelajaran yang menyenangkan, seperti dengan cara bernyanyi, menggunakan teks cerita, mendongeng dan bermain peran (Aini \& Relmasira, 2018).

Kedua Kemampuan kognitif anak usia 8 tahun (kelas 2 SD/MI) Kemampuan kognitif yang dimiliki pada fase ini tidak lebih buruk dari fase sebelumnya. Di dalam dunia pendidikan anak pada usia 8 tahun mulai menapaki jenjang $\mathrm{C} 2$ yaitu memahami sesuatu dan menuju tahap C3 yaitu menerapkan sesuatu yang lebih baik dan terampil. Menurut Piaget Ketika anak usia 7 tahun hingga 8 tahun anak mampu memahami korelasi yang ada pada kumpulan tingkat dan mampu menyusun berdasarkan ukurannya .

Pembelajaran matematis pada usia ini anak dapat menerapkan ketrampilannya, misal saat pembelajaran anak diberi batang coklat, ia akan mampu untuk mengurutkan batang coklat dari yang terkecil hingga yang terbesar, tetapi ketika dihadapkan dengan soal yang sama tetapi tidak menghadirkan objeknya secara nyata, maka anak akan merasa kesulitan dalam menjawab soal tersebut.

Metode pembelajarannya dapat dilakukan di alam terbuka atau di luar kelas . Fase ini anak membutuhkan pembelajaran di luar kelas dalam sekali tempo untuk mengantisipasi kejenuhan yang mungkin terjadi.Disamping itu juga dengan kegiatan belajar di alam terbuka juga dapat menghadirkan objek yang ada secara langsung sehingga anak mudah memahaminya. Jadi pada fase ini sebenarnya anak sudah bisa untuk diajak belajar berbau formal akan tetapi sesekali membutuhkan kegiatan pembelajaran yang asik seperti pembelajaran berbasis permainan (Mungzilina et al., 2018).

Ketiga Kemampuan kognitif anak usia 9 tahun (kelas tiga SD/MI) Pada fase ini, kemampuan kognitif semakin meningkat. Anak sudah dapat memecahkan masalah yang lebih rumit, karena anak sudah banyak memiliki pengetahuan, wawasan dan pengalaman dari proses-proses sebelumnya. Anak sudah memasuki tingkat C3 yaitu menerapkan. Kecerdasan anak di bidang mata pelajaran matematika sudah semakin meningkat, anak bukan saja mengetahui bagun-bangun datar tetapi sudah bisa 
menghitung luas bangundatar dan sudah bisa mengenal bangun ruang.

Kemampuan matematika anak pada kelas 3semakin baik, anak tidak hanya mengenal jenis bangun datar, tetapi sudah dapat menghitung luas bangun datar dan mengenal bangun ruang. Anak juga memahami proses perubahan bentuk bangun, misalnya bangun persegi dapat dibentuk menjadi dua bangun segitiga atau berbentuk jajar genjang. Anak dapat secara langsung menghitung angka dalam pikirannya tanpa menghitung dengan cara manual atau menulis. Contoh, Ketika anak ditanya tentang perkalian angka puluhan dengan satuan, anak bisa menjawab secara spontan, tetapi ketika mengalikan angka puluhan dengan puluhan bahkan ratusan, anak belum bisa menjawabnya secara spontan tanpa dengan bantuan perhitungan manual.

Metode pembelajaran pada fase ini, sudah bisa diterapkan pembelajaran dengan diskusi kelompok. Guru tetap harus dapat mengontrol dan memperhatikan kegiatan pelaksanaannya, karena kemampuan anak untuk berdiskusi masih terbatas, kemampuan beride dan keterampilan bekerja samanya masih perlu dikembangkan. Selain dari itu, perhatian anak juga mudah goyah, oleh karenanya dibutuhkan kontrol yang penuh dari seorang guru(Nengah Kelirik, 2013).

Keempat Kemampuan kognitif anak usia 10 tahun(kelas empat SD/MI) Pada fase ini anak memiliki daya kritis yang semakin baik, anak dapat menelaah suatu masalah secara mendalam dengan berbagai dimensi. Kemampuan kogntif pada ranah C3 yaitu menerapkan, anak bukan hanya mampu untuk menghitung dan mengubah melainkan sudah dapat membandingkan objek-objek yang ada. Di usia 9 tahun hingga 10 tahun anak mulai masuk pada jenjang $\mathrm{C} 4$ yaitu menganalisis, dimana anak mampu dalam hal penguraian pada keadaan sesuai bagian yang lebih khusus serta dapat memahami korelasi terkait bagian korelasi satu dengan korelasi lainnya. Anak dapat menganalisis, mengkontraskan dan menghubungkan teori dengan fakta untuk menarik kesimpulan. Anak dapat menarik kesimpulan nilai-nilai baik dan buruk yang termuat di dalamnya. Pada dasarnya, usia 10 tahun anak sudah memasuki ranah sintesis (C5) tetapi masih pada level yang sangat sederhana., memecahkan soal yang berbentuk narasi atau cerita (Rusman, 2012: 202).

Kemampuan matematika anak pada fase ini sudah semakin baik, anak dapat menyelesaikan soal pembelajaran yang lebih rumit. Contohnya dalam mengoperasikan bilangan pecahan dan desimal, menghitung luas sebagian dari suatu bangun datar, menghitung volume bangun ruang dan menghitung perubahan ukuran benda, seperti kilo gram ke gram, centi meter ke meter dan lain sebagainya. Serta memcahkan soal dalam bentuk narasi atau cerita.

Model pembelajaran kooperatif learning dirasa tepat untuk pendektan pembeljaran pada fase ini. Pada fase yang disebuat Student-Teams-Achievment Divisions. Tipe pembelajarannya adalah kooperatif dan pelaksanaannya melalui kelompok-kelompok kecil beranggotakan 4 hingga 5 anak, setiap kelompok diberikan tugas untuk diskusikan dan kemudian dilanjut dengan tanya jawab. Model pembelajaran kooperatif dapat melatih anak dalam berkomunikasi (sharing), bertkukar ide dan pendapat bersama temannya untuk memecahkan masalah. Anak dapat diajak bernalar kritis terhadap objek-objek yang belum mereka ketahui sebelumnya (Maulana et al., 2018).

Kelima perkembangan kognitif anak usia sebelas sampai dua belas tahun ke 
atas(Kelas lima dan kelas enam SD/MI) Pada usia sebelumnya, anak bisa berfikir logis dan sistematis yang mangacu terhadap objek empirik (nyata) yang dapat di tangkap oleh indra. Fase anak yang berada pada usia 11 tahun hingga 12 tahun ke atas, anak mulai mampu berpikir pada sesuatu yang berkemungkinan terjadi. Fase ini disebut dengan fase operasional formal.Menurut Willam Crain (Yudi Santoso, 2014: 200) Anak sudah dapat berfikir tentang objek yang bersifat abstrak dan mampu berfikir secara kritis, ketika dihadapkan dengan masalah, anak memahami sebab-akibat, kemudian menyusun langkah untuk menyelesaikannya. kompetensi kogitif anak pada usia 11 sampai 12 tahun sudah dapat berfikir strategis sistematis.

Kemampuan matematika anak semakin kompleks, jika sebelumnya hanya dapat menghitung luas pada bangun datar, dalam tahap ini anak mulai mampu menghitung luas, keliling serta volume bangun ruang. Anak dapat mengerjakan soal-soal yang rumit, seperti operasi akar dan mengoperasikan angka yang bernominal tinggi (ribuan dan jutaan).

Model pembelajaran pada fase ini sudah bisa diterapkan pembelajaran bermodel terpusat kepada peserta didik atau yang disebut student center, diantara model tersebut adalah model inkuiri yaitu kegiatan belajar mengajar dengan pola dari suatu pengamatan menjadi pemahaman. Pada tahap ini anak mampu berfikir dan daya kritis tingkat tinggi. Pendekatan pembelajaran yang sesuai pada usia ini adalah kontruktivisme. Kontruktivisme merupakan sesuatu yang menjadi landasan dasar suatu paradigma dimana proses pembentukan pengetahuan pada individu tidak dengan mudah menghasilkan transferan ilmu saja, melainkan dari aktifitas mental yang didukung oleh suatu pengalaman yang panjang untuk membangun pemahaman secara individu (Ani et al., 2016).

\section{UCAPAN TERIMA KASIH}

Terima kasih diberikan kepada dosen pengampu mata kuliah Perkembangan Peserta didik dari Universitas Muhammadiyah Surakarta. Selain itu terima kasih diberikan kepada teman-teman yang sudah saling membantu dalam menyusun artikel ini.

\section{KESIMPULAN}

Teori Perkembangan kognitif ini Jean Piaget ia berpendapat terdapat tiga aspek dalam perkembangan kognitif setiap individu, meliputi:isi,struktur, dan fungsi kognitif. Perkembangan kognitif pada tahap operasional konkret (7-12 tahun) dalam pembelajaran matematika ini berbeda-beda hampir pada setiap tahap usianya.

Tahapan perkembangan anak mempengaruhi bagaimana cara anak belajar dan bagaimana cara mendapat pengetahuan baru. Tahapan perkembangan belajar anak selain dipengaruhi factor tingkat pemahaman siswa yang berbeda-beda, juga model dan metode serta penanganan yang digunakan harus bervariatif dan disesuaikan dengan tahapan usianya. Pembelajran dengan pendekatan perkembangan kogniti anak dapat menjadi pedoman guru dalam mengajar sehingga pembelajaran menjadi lebih efektif, efisien, dan tepat sasaran. Terlebih dapat mendorong tercapainya tujuan pendidikan nasional.

\section{DAFTAR RUJUKAN}

Aini, Q., \& Relmasira, S. C. (2018). Penerapan Pembelajaran Tematik Integratif Berbasis Kontekstual Untuk Meningkatkan Keaktifan Dan Hasil 
Belajar Siswa Kelas $1 \quad S d$. 8285(November), 124-132.

Ani, N. K., Garminah, N. N., \& Suartama, I. kadek. (2016). Pengaruh Model Pembelajaran CRH Berbantuan LKS Siswa Kelas IV SD. E-Journal PGSD Universitas Pendidikan Ganesha, 4(1), $1-12$.

https://ejournal.undiksha.ac.id/index.ph p/JJPGSD/article/viewFile/7331/5001

Anugraheni, I. (2018). Pengembangan Perangkat Pembelajaran Matematika Berbasis Pendidikan Karakter Kreatif Di Sekolah Dasar. Refleksi Edukatika: Jurnal Ilmiah Kependidikan, 8(2). https://doi.org/10.24176/re.v8i2.2351

Anwar, Chairul. (2017). Teori - teori Pendidikan Klasik Hingga Kontemporer. Yogyakarta : IRCiSoD.

Barlia, L. (2011). Konstruktivisme dalam pembelajaran sains di SD: tinjauan epistemologi, ontologi, dan keraguan dalam praksisnya. Jurnal Cakrawala Pendidikan, 3(3).

Basri, H. (2018). Kemampuan Kognitif Dalam Meningkatkan Efektivitas Pembelajaran Ilmu Sosial Bagi Siswa Sekolah Dasar. Jurnal Penelitian Pendidikan, 18(1), 1-9. https://doi.org/10.17509/jpp.v18i1.110 54

Bujuri, D. A. (2018). Analisis perkembangan kognitif anak usia dasar dan implikasinya dalam kegiatan belajar mengajar. LITERASI (Jurnal Ilmu Pendidikan), 9(1), 37-50.

Crain, Willam. (2014). Teori Perkembangan: Konsepdan Aplikasi, terj. Yudi Santoso, Cet. Ke- 2. Yogyakarta: Pustaka Belajar

Estini, D. G. W. (2015, October). Aktualisasi pemikiran Jean Piaget dalam implementasi kurikulum 2013 (Suatu kajian teoritis). In Prosiding Seminar Nasional MIPA.

Feldman dan Old Papalia. (2008). Human Dovelopment (Psikologi Perkembagan) : Bagian I s/d IV, terj.

Adnyana, G. P. (2012). Keterampilan Berpikir Kritis dan Pemahaman
Konsep Siswa pada Model Siklus Belajar Hipotetis Deduktif. Jurnal Pendidikan dan Pengajaran, 45(3).

Hapsari, T. S. (2011). Penerapan model pembelajaran konstruktivisme untuk meningkatkan hasil belajar IPA. Jurnal Pendidikan Penabur, 16(10), 34-45.

Mifroh, N. (2020). Teori Perkembangan Kognitif Jean Piaget dan Implementasinya Dalam Pembelajaran di SD/MI. JPT: Jurnal Pendidikan Tematik, 1(3), 253-263.

Juwantara, R. A. (2019). Analisis Teori Perkembangan Kognitif Piaget Pada Tahap Anak Usia Operasional Konkret 7-12 Tahun Dalam Pembelajaran Matematika. Jurnal Ilmiah Pendidikan Guru Madrasah Ibtidaiyah,9(1), 2734.

Khaulani, F., S, N., \& Irdamurni, I. (2020). Fase Dan Tugas Perkembangan Anak Sekolah Dasar. Jurnal Ilmiah Pendidikan Dasar, 7(1), 51. https://doi.org/10.30659/pendas.7.1.5159

Khiyarusoleh, U. (2016). Konsep Dasar Perkembangan Kognitif Pada Anak Menurut Jean Piaget. Dialektika Jurusan PGSD, 5(1), 1-10.

King, Laura A. Tt. Psikologi Umum Sebuah Pandangan Apresiatif, (Terj Deresi Opi PerdanaYanti), Cet. 1, Jakarta: Selemba Humanika

Latifah, U. (2017). Aspek perkembangan pada anak Sekolah Dasar: Masalah dan perkembangannya. Academica:

Journal of Multidisciplinary Studies, 1(2), 185-196.

Lexy, Moleong, J. (2006). Metodologi Penelitian Kualitatif. Bandung: Remaja Rosdakarya.

Margono. (2002). Metodologi Penelitian pendidikan. Jakarta : Rineka Cipta

Maulana, U., Kristin, F., \& Anugraheni, I. (2018). Efektivitas Cooperative Learning Tipe The Power Of Two Terhadap Kemampuan Pemecahan Masalah Matematika Siswa Kelas 4 Sd Pendidikan Guru Sekolah Dasar , Universitas Kristen Satya Wacana 
Salatiga. V(3), 29-33.

Mifroh, N. (2020). Teori Perkembangan Kognitif Jean Piaget dan Implementasinya dalam Pembelajaran di SD/MI. Jurnal Pendidikan Tematik (JPT), 1(3), 253-263.

Mu'min, S. A. (2013). Teori Perkembangan Kognitif Jean Piaget. Al-TA'DIB: Jurnal Kajian Ilmu Kependidikan, 6(1), 89-99.

Mungzilina, A. K., Kristin, F., \& Anugraheni, I. (2018). Penerapan Model Pembelajaran Problem Based Learning Untuk Meningkatkan Tanggung Jawab Dan Hasil Belajar Siswa Kelas $2 \mathrm{Sd}$. NATURALISTIC: Jurnal Kajian Penelitian Pendidikan Dan Pembelajaran, 2(2), 184-195. https://doi.org/10.35568/naturalistic.v2i 2.209

Muslihatun, A., Cahyaningtyas, L., Narendra, R., \& Hasaleh, L. (2019).
Pemanfaatan Permainan Tradisional Untuk Media Pembelajaran : Congklak Bilangan Sebagai Inovasi Pembelajaran Matematika Pendahuluan. 15(1), 14-22.

Nengah Kelirik. (2013). Penerapan Metode Diskusi Kelompok Untuk Meningkatkan Hasil Belajar Ipa Di Sekolah Dasar Negeri 1 Sukadana. Journal of Chemical Information and Modeling, 53(9), 1689-1699.

Safitri, N. U. R. A., Pendidikan, J., Madrasah, G., Tarbiyah, F., \& Ilmu, D. A. N. (2021). I Buku Siswa Senang Belajar Matematika Kelas Iv Kurikulum 2013 (Prespektif Teori Perkembangan Kognitif Jean Piaget). 2013(April).

Waseso, H. P. (2018). Kurikulum 2013 dalam prespektif teori pembelajaran konstruktivis. TA'LIM: Jurnal Studi Pendidikan Islam, 1(1), 59-72. 